\title{
MORPHOGENIC PROCESSES IN CALLUS TISSUE CULTURES AND DE NOVO REGENERATION OF PLANTS IN ACTINIDIA CHINENSIS PLANCH.
}

\author{
Adela Ludvová ${ }^{1}$, Mária Gabriela OstroluCKÁ ${ }^{2}$ \\ ${ }^{1}$ Institute of Forest Ecology, Slovak Academy of Sciences, \\ Zvolen, Branch of Woody Plants Biology, Akademická 2, \\ 94901 Nitra, Slovak Republic \\ ${ }^{2}$ Institute of Plant Genetics, Slovak Academy of Sciences, \\ Akademická 2, 95007 Nitra, Slovak Republic
}

(Received: September 1, 1997. Accepted: March 17, 1998)

\begin{abstract}
Our experiments have confirmed the considerable disposition of leaf explants of Actinidia chinensis Planch. for induction and intensive proliferation of callus cultures, as well as, a possibility to regulate morhogenesis in in vitro conditions. Under specific culture conditions the morphogenic potential of callus cells of Actinidia chinensis was manifested both in organogenesis and somatic embryogenesis. Organogenesis was represented by induction of adventitious buds and regeneration shoots on the modified MS culture medium (Murashige and Skoog 1962) with BAP in combination with $\mathrm{GA}_{3}$ (each $1.0 \mathrm{mg} . \mathrm{I}^{-1}$ ). Rooting of shoots was successful on modified MS medium containing IBA $\left(0.5-1.0 \mathrm{mg} . \mathrm{I}^{-1}\right)$.

Histological studies of callus tissues revealed their structural heterogeneity. Morphogenic processes in the callus were characterized by the appearance of meristematic zones and vascular elements. The formation of apical meristem, leaf primordia and finally shoot development proved de novo regeneration in callus culture.

The obtained results demonstrate a possibility of plant regeneration through indirect organogenesis, which can be used for propagation of Actinidia chinensis Planch.
\end{abstract}

KEY WORDS: Actinidia chinensis, leaf explants, callus culture, morphogenic responses.

\section{INTRODUCTION}

Callus cultures are excellent objects for the study of differentiation of cells and tissues. An important aspect of callus cells and tissues is the ability to regenerate plants. Many woody species are difficult to regenerate from callus cultures and they are propagated for commercial purpose by apical and axillary buds proliferation. Certain plant species are able to realize the in vitro process of dedifferentiation and redifferentiation, but this ability is often limited, especially in forest trees.

The successful callus induction and realization of morphogenic responses (organogenesis, somatic embryogenesis) in callus tissue cultures depend on the plant species and on the genotype of the donor plant and even on an explant type. Composition of the culture medium, mainly the content of growth regulators influence the mentioned processes to a considerable degree. Endogenous phytohormones present in explants play also a great role. Many authors (Opatrný 1983, Bonga, Aderkas 1992, Georgie 1993 and others) emphasized the mechanism of growth regulators effect on the regulation of the morphogenesis in tissue cultures.

Several recent studies have confirmed the morphogenetic potential of callus cultures derived from leaves of trees (Jones
1993) and also presented an efficient adventitious shoots development from callus cultures (Fasolo et al. 1989, Escalettes, Dosba 1993, Economou and Maloupa 1995).

This paper is intended to present the effect of growth regulators on induction of callus culture, observations of the morphogenetic responses in callus cultures derived from leaf explants of Actinidia chinensis and also the de novo in vitro plant regeneration. Histological investigations of the structural changes in callus tissue cultures and alternatives of morphogenetic response are illustrated.

\section{MATERIAL AND METHODS}

Leaf explants were separated from shoot cultures obtained from axillary buds of about 5 -yr old plants (from the Botanical Garden of the Slovak Agricultural University in Nitra). Leaf segments were placed with overleaf into Petri dishes (25 $\mathrm{ml} / \mathrm{dish}$ ) with a medium. Basal modified medium of Murashige and Skoog (1962) (with a half concentration of macroelements) supplemented with $3 \%(\mathrm{w} / \mathrm{v})$ of sucrose and $6 \%$ $(\mathrm{w} / \mathrm{v})$ of agar was used. Experimental variants the MS medium were supplemented with BAP, 2.4-D, $\mathrm{GA}_{3}$ (each 1.0 
mg. $\mathrm{I}^{-1}$ ) as sole growth regulators or combinations of BAP with 2.4-D, BAP with $\mathrm{GA}_{3}$ and 2.4-D with $\mathrm{GA}_{3}$ (each $1.0 \mathrm{mg}$. $\mathrm{I}^{-1}$ ) were used. $\mathrm{pH}$ of culture media was adjusted to 5.6-5.7. Cultures were incubated at $25-28^{\circ} \mathrm{C}$ and a $16 / 8$ hour photoperiod with light intensity of $60 \mu \mathrm{E} \cdot \mathrm{m}^{-2} . \mathrm{s}^{-1}$ After one month, when callus was induced, the explants with callus were transferred into a $100 \mathrm{ml}$ conical flasks (containing $25 \mathrm{ml}$ of the medium). The cultures were further monthly subcultured on fresh media.

Shoots regenerated from callus tissue cultures were transferred on a rooting medium containing IBA $\left(0.5-1.0 \mathrm{mg}^{\mathrm{1}^{-1}}\right)$. The regenerated plantlets were transferred into a substrate consisting of perlite and peat $(1: 2)$ and placed in a greenhouse.

For histological studies the callus tissue samples (derived on the medium with BAP and $\mathrm{GA}_{3}$ ) after one month and after three months of culture were fixed in FAA $(70 \mathrm{w} / \mathrm{v}$ ethanol: glacial acetic acid: formalin - 18:1:1), dehydrated (ethanolxylol) and embedded in paraffin wax. Sections (10-13 $\mu \mathrm{m}$ thick) were stained with Ehrlich's hematoxylin.

\section{RESULTS AND DISCUSSION}

The micropropagation of the species Actinidia chinensis Planch. was obtained in in vitro conditions by cultivation of different explants - root, zygotic embryos, stamens and first of all apical and axillary buds (Harada 1975, Wang et al. 1982, Brossard-Chriqui, Tripathi 1984, Standardi 1983, Monette 1986, Kamenická, Rypák 1989a, Cholvadová 1990, Ostrolucká 1993). The results of the above authors and our own results have confirmed a high regeneration potential and considerable flexibility of Actinidia chinensis in morphogenic responses in comparison to other woody plants.

The presence of growth regulators in the culture medium has considerably affected the morphogenic processes. The importance of growth regulators for the induction of cell morphogenic response was confirmed by the fact, that leaf seg- ments of Actinidia chinensis cultured on a modified MS medium without growth regulators failed to induce callus and gradually necrotized. The effects of individual growth substances and their combinations (in concentration of $1 \mathrm{mg}^{-1} \mathrm{l}^{-1}$ ) on callus induction and on the character of morphogenic processes were different (Table 1).

The initiation of callus induction occurred on the overleaf segments and on their margins on the 6th-10th day. The callus overgrew the whole surface of the primary explant. Callus formation was lower on the medium containing sole growth regulator (with $\mathrm{BAP}-30 \%$, with $\mathrm{GA}_{3}-68 \%$ ) (Table 1). The $30 \%$ frequency of initiation on BAP was the lowest one obtained in our experiments. The combination BAP and $\mathrm{GA}_{3}$ gave a higher initiation frequency $(86 \%)$. Cultures growing on the medium with combined $\mathrm{BAP}$ and $\mathrm{GA}_{3}$ retained their vitality for a long time what can be ascribed as a positive effect of $\mathrm{GA}_{3}$. The medium with combined BAP and 2.4-D appeared to be the most efficient $(98 \%)$ in callus induction (Fig. 1). Similarly some authors have found that callus induction depends on the presence of auxins in combination with cytokinins in culture media (Kamenická, Rypák 1989, Bonga, Aderkas 1992). Monette (1986) reported that callus proliferation in Actinidia chinensis was markedly stimulated by BAP in combination with NAA.

At the same time we observed a specific effect of individual growth substances on the callus consistence and colour (Table 1). Callus on media containing BAP, $\mathrm{GA}_{3}$ and BAP in combination with 2.4-D was white, of compact consistence. On a medium with 2.4-D, BAP in combination with $\mathrm{GA}_{3}$ and 2.4-D with $\mathrm{GA}_{3}$ callus was white, later light green to green and friable consistence. On a medium with $\mathrm{BAP}$ and $\mathrm{GA}_{3}$ reddish areas appeared on the callus which is supposed to be anthocyans synthesis manifestation. We found that the callus consistence can change after changing the medium composition and longer culture. For instance the friable callus induced on the medium 2.4-D became compact after three months of culture on the medium with BAP and 2.4-D. A regular subculturing

TABLE 1. The callus initiation and variability of morphogenic response in the callus cultures of Actinidia chinensis

\begin{tabular}{|c|c|c|c|c|c|c|c|c|c|c|c|c|c|c|}
\hline \multirow[t]{4}{*}{ Morphogenic response } & \multicolumn{14}{|c|}{ Variants of culture media } \\
\hline & \multicolumn{14}{|c|}{ Growth substances and their combinations (each $1.0 \mathrm{~m}=\mathrm{mg} . \mathrm{l}^{-1}$ ) } \\
\hline & \multicolumn{2}{|c|}{ BAP } & \multicolumn{2}{|c|}{$2.4-\mathrm{D}$} & \multicolumn{2}{|c|}{$\mathbf{G A}_{3}$} & \multicolumn{2}{|c|}{ BAP, 2.4-D } & \multicolumn{2}{|c|}{ BAP, GA3 } & \multicolumn{2}{|c|}{ 2.4-D, GA3 } & \multicolumn{2}{|c|}{ C } \\
\hline & A & B & A & B & A & B & A & B & A & B & A & B & A & B \\
\hline Callogenesis & 50 & 30 & 50 & 78 & 50 & 68 & 50 & 98 & 50 & 86 & 50 & 80 & 50 & - \\
\hline The consistency of callus & \multicolumn{2}{|c|}{$\mathrm{CC}$} & \multicolumn{2}{|c|}{ FC } & \multicolumn{2}{|c|}{$\mathrm{CC}$} & \multicolumn{2}{|c|}{$\mathrm{CC}$} & \multicolumn{2}{|c|}{$\mathrm{FC}$} & \multicolumn{2}{|c|}{$\mathrm{FC}$} & & \\
\hline The colour of callus & \multicolumn{2}{|c|}{ W } & \multicolumn{2}{|c|}{ W } & \multicolumn{2}{|c|}{ W } & \multicolumn{2}{|c|}{ W } & \multicolumn{2}{|c|}{ W-LG-G } & \multicolumn{2}{|c|}{ W-LG } & & \\
\hline Other responses & & & & & & & & & & & & & & \\
\hline \multirow[t]{2}{*}{ Organogenesis } & & & & & & & & & & & & & & \\
\hline & & & & & & & \multicolumn{2}{|c|}{$\mathrm{R}$} & & & \multicolumn{2}{|c|}{$\mathrm{R}$} & & \\
\hline Somatic embryogenesis & & & & & & & \multicolumn{2}{|c|}{$\mathrm{E}$} & & & & & & \\
\hline
\end{tabular}

A - number of primary explants (leaf segments)

B - primary explants with callus initiation (\%)

C - MS medium without growth substances

$\mathrm{CC}$ - callus of compact consistency

FC - callus of friable consistency

W - callus of white colour
LG - callus of light green colour

$\mathrm{G}$ - callus of green colour

$\mathrm{AN}$ - anthocyanin synthesis

$\mathrm{R}$ - differentiation of roots

$\mathrm{S}$ - differentiation of shoots

E - embryogenic structures 

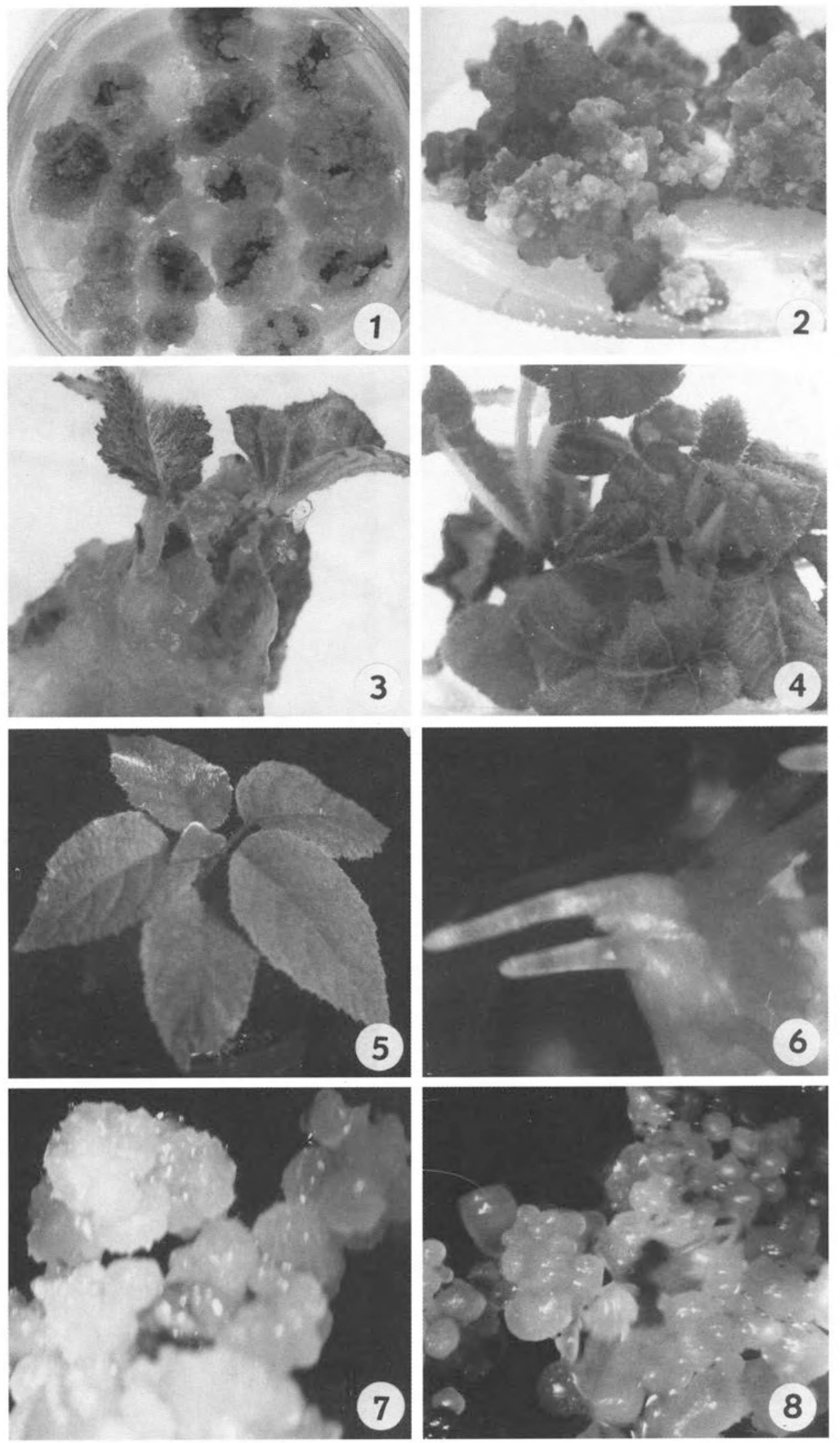

Fig. 1. Induction of callus from leaf segments on modified MS medium supplemented with BAP and 2,4-D (each 1 mg. $1^{-1}$ ) after 30 days cultivation.

Fig. 2. Callus mass derived from leaf segments on modified MS medium with BAP and $\mathrm{GA}_{3}$ (each $1.0 \mathrm{mg} . \mathrm{I}^{-1}$ ) after three months of culture and formation of adventitious buds in callus.

Figs 3, 4. Shoot differentiation from leaf callus and their development on MS medium containing BAP a GA 3 (each 1.0 mg. ${ }^{-1}$ ).

Fig. 5. The rooted plantlets two months after transplantation into substrate.

Fig. 6. Direct differentiation of roots on the main vein of leaf explant on modified MS medium with BAP and 2,4-D and GA 3 (each 1.0 mg. $1^{-1}$ ). Fig. 7. Embryogenic callus derived from leaf segments on modified MS medium supplemented with BAP a 2,4-D (each 1.0 mg. $1^{-1}$ ). Fig. 8. Futher development of embryogenic callus - numerous globular somatic embryos. 

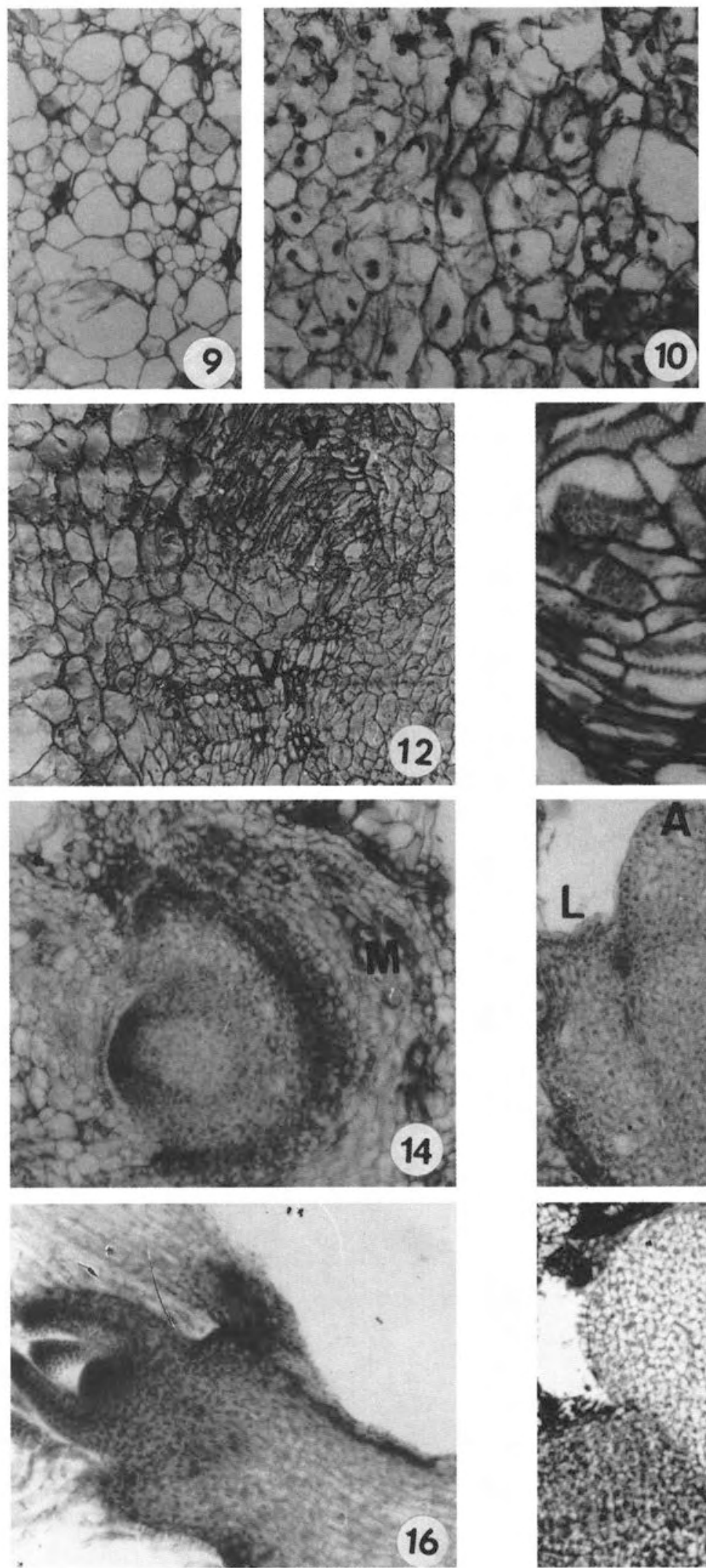
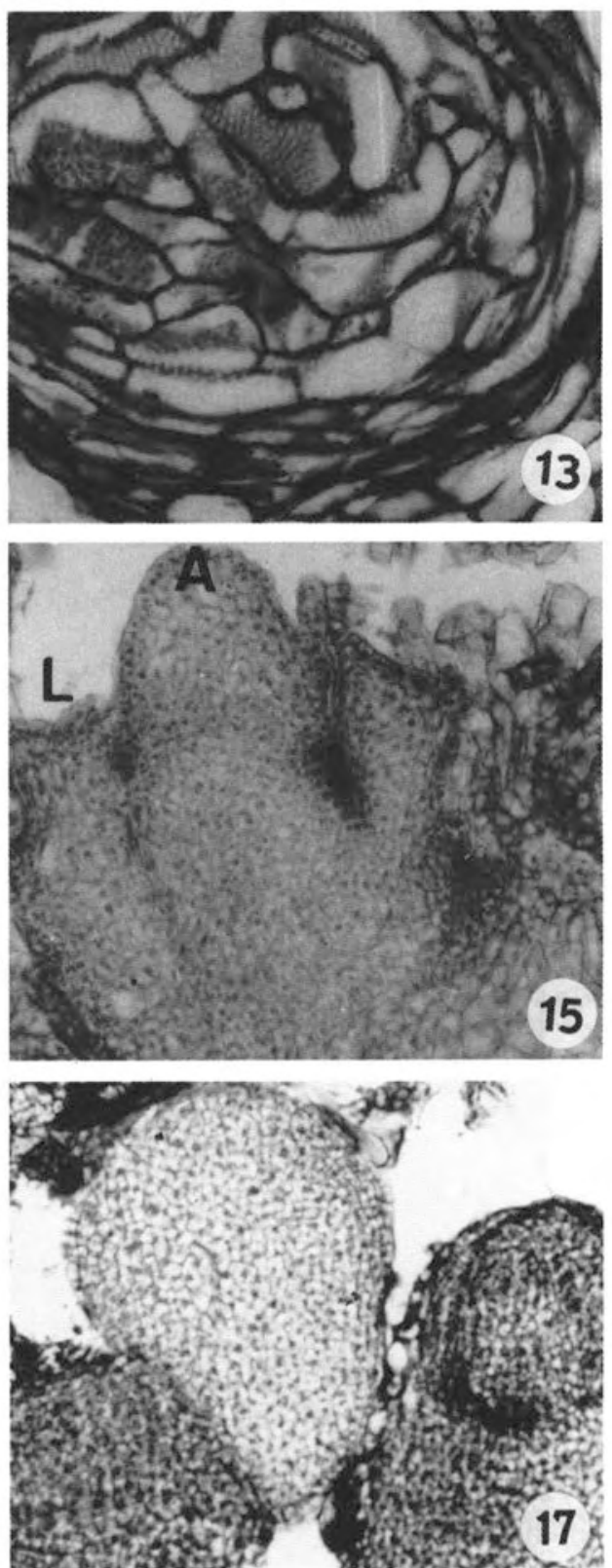

Morpho-histological study of organogenic callus induced from leaf segments on modified MS medium with BAP and GA3 (each $1.0 \mathrm{mg}$. $\mathrm{I}^{-1}$ ) (Figs 9-17).

Fig. 9. Vacuolated parenchymatic cells of irregular shape in callus after 30 days of cultivation.

Fig. 10. Morphological variability of parenchymatic cells with conspicuous nuclei observed in callus after three months of cultivation.

Fig. 11. Accumulation of starch grains (S) in callus cells.

Figs 12-13. Formation of vascular elements (V) in callus tissue.

Figs 14-15. Indirect organogenesis is ilustrated by occurrence of meristematic zones (M), formation of apical meristem (M) and of leaf primordia (L).

Fig. 16. Development of shoot of adventitious origin.

Fig. 17. Differentiation of multicellular globular structures. 
(every 30 days) favourably affected the continuous growth of the callus culture in all variants of culture media.

A possibility to regulate morphogenesis in in vitro conditions has been confirmed in our experiments (Table 1). The leaf explants of the species Actinidia chinensis manifested an ability not only for initiation of the callus culture, but also for redifferentiation of induced callus. Under certain culture conditions the callus cells morphogenic potential was manifested both towards organogenesis (Figs 1-4) and somatic embryogenesis (Figs 6-8). A favourable effect of growth regulators in their synergic activity was comfirmed. In some parts of the callus on the medium BAP in combination with 2.4-D root formation occurred and also differentiation of roots have been observed on the medium with $\mathrm{GA}_{3}$ and 2.4-D, directly along the main midrib (Fig. 5). During root growth a polarity disturbance - negative geotropism was observed, which was also recorded by Kamenická and Rypák (1989) in Castanea sativa. We think that the stimulative effect on the rhizogenesis induction can be ascribed to 2.4-D. Vieitez et al. (1978) reported a positive effect of BAP on the rhizogenesis process in Castanea sativa.

The morphogenic potential and regeneration ability of callus culture enabled adventitious buds induction and subsequent regeneration of shoots of fruit trees and other woody species (Miguel et al., 1996; Vieitez, San-José, 1996). The callus culture of Actinidia derived from leaves can also be used for propagation because it is very effective for induction of adventitious shoots. Our experiments revealed that numerous buds and adventive shoots were developed on a medium containing BAP and $\mathrm{GA}_{3}$ (Figs 3,4 ). We recorded an efficient proliferation of shoots in the callus culture of Actinidia chinensis. Each callus produced 15-20 shoots. Kamenická and Rypák (1989) reached multiplication of Actinidia shoots on a medium containing BAP $\left(1.0 \mathrm{mg}^{-1} \mathrm{l}^{-1}\right)$ and $\mathrm{GA}_{3}\left(2.0 \mathrm{mg} . \mathrm{l}^{-1}\right)$ through a direct organogenesis. Cholvadová (1990) points to an efficient effect of zeatine in the organogenesis process in Actinidia.

Regenerated shoots (from 2 to $2.5 \mathrm{~cm}$ in height) were excised and transferred on a rooting medium (MS with a half concentration of macroelements) containing IBA (0.5-1.0 mg. $1^{-1}$ ) where the rooting was successful (to $92-98 \%$ ). The obtained regenerated plants are able of adaptation and they also grow intensively in in vivo conditions (Fig. 5).

The proliferation of embryogenic callus and differentiation of embryogenic structures (Figs 7,8) were observed on the medium with BAP in combination with 2.4-D. Embryogenic structures on the level of globular and torpedo stages were attacked by an infection after subculturing in consequence of which we did not succeed in obtaining somatic embryos. The positive BAP and 2.4-D effect on differentiation of somatic embryos has been recorded e. g. in oak (Ostrolucká and Krajmerová 1996).

The obtained results demonstrate a reproducible plant regeneration system of indirect organogenesis and the Actinidia callus culture ability of redifferentiation and de novo regeneration. This system enables a high plant production, but on the other hand does not guarantee the genetic stability of regenerants.

Histological investigations of callus tissue induced on BAP medium in combination with $\mathrm{GA}_{3}$ showed that after 30 days the callus consisted of parenchymatic cells with intercellular, spaces. Parenchymatic cells were irregularly shaped, of different size and highly vacuolated (Fig. 9).

The studies on callus tissues revealed their structural heterogeneity. Different parts of the callus gave different histological patterns. Parenchymatic cells of different size, with one and sometimes even with two nuclei appeared what can indicate a different degree of their ploidity. Strongly vacuolized cells were also observed (Fig. 10).

Further observations of intensively proliferating callus (carried out three months later) on BAP medium with $\mathrm{GA}_{3}$ have confirmed the heterogenous morphogenic activity of some parts of the callus, whereas other parts remained amorphous without organogenic manifestations. In some callus cells many starch grains appeared (Fig. 11). We suppose that these starch grains are a source of reserve substances and are important in the process of organogenesis. The anatomical studies of shoot development of kiwifruit long term callus culture were carried out by Jásik and Lux (1992). They have recorded in detail the starch synthesis in the organogenic callus.

Morphogenic processes were correlated with the changes in callus culture. The differentiation of callus cells led to the formation of numerous tracheids of different length and tracheal zones (Figs 12, 13) as well as of meristematic centres (Fig. 14). The presence of vascular elements in a non-organized parenchymatic tissue enables the transport of growth regulators and nutrients and supports local activation of cell division. Opatrný (1977) reported that a distinct differentiation of tracheids occurs during the so-called process of an active state of the tissue and the appearance of tracheid elements can be the first degree of regeneration of organs in a non-organized tissue. According to the author, the active state of the tissue the cell division is preceded by utilization of the starch grains in cells.

The formation of apical meristem, leaf primordia and multiple shoots illustrates the regeneration in callus cultures (Figs 15, 16, 17).

\section{LITERATURE CITED}

BONGA J.M., ADERKAS P. von, 1992. In vitro culture of Trees. Forestry Sciences 38, Kluwer Acad. Publ., Dordrecht, The Netherlands, pp. 206.

BROSSARD-CHRIQUI D., TRIPATHI B.L., 1984. Comparasion des aptitudes morpho génétique des étamines fertiles on steriles d Actinidia chinensis cultiveés in vitro. Can. Jour. Bot. 62: 1940-1946.

ECONOMOU A.S., MALOUPA E.M., 1995. Regeneration of Elaeagnus angustifolia from leaf segments of in vitro derived shoots. Plant Cell Tissue and Organ Culture 40: 285-288.

ESCALETTES V., DOSBA F., 1993. In vitro adventitious shoot regeneration from leaves of Prunus spp. Plant Sci. 90: 201-209.

FASOLO F., ZIMMERMAN R.H., FORDHAM I., 1989. Adventitious shoot formation on excised leaves of in vitro grown shoots of apple cultivars. Plant Cell Tissue and Organ Culture 16: 75-87.

GEORGIE E.F., 1993. Plant Propagation by Tissue Culture, Part 1, The Technology, Exegetics Ltd., pp. 420-479.

HARADA H., 1975. In vitro organ culture of Actinidia chinensis Pl. as a technique for vegetative multiplica tion. J. Hort. Sci. 50: 81-83.

CHOLVADOVÁ B., 1990. Micropropagation of Actinidia chinen sis (Planch.) in in vitro conditions (in Slovak), p. 99. In: Manipulace in vitro u vyšších rostlin (In vitro Manipulation in Higher Plants), Sborník z celostátní konference, Olomouc.

JÁSIK J., LUX A., 1992. Anatomical study of shoot development in long-term callus cultures of kiwifruit (Actinidia deliciosa var. deliciosa). Biol. Plant. (Suppl.) 34: 540.

KAMENICKÁ A., RYPÁK M., 1989. Regeneration of kiwifruit (Actinidia chinensis Planch.) in vitro culture (in Slovak). Pol'nohospodárstvo 35: 811-818.

KAMENICKÁ A., RYPÁK M., 1989 a. Explants in plant propagation (in Slovak). Acta Dendrobiol., Veda, SAV, Bratislava, pp. 158.

MIGUEL M.C., DRUART P., OLIVIERA M., 1996. Shoot regeneration from adventitious buds induced on juvenile and adult almond (Prunus dulcis Mill.) explants. In vitro Cell Dev. Biol. Plant 32: 148-153. 
MONETTE P.L., 1986. Micropropagation of kiwifruit using non-axenic shoot tips. Plant Cell Tissue Organ Culture 6: 73-82.

MURASHIGE T., SKOOG F., 1962. A revised medium for rapid growth and bioassays with tobacco tissue cultures. Physiol. Plant. 15: 473-497.

OPATRNÝ Z., 1977. Induction of morphogenesis in explant cultures problems and reflections (in Czech), pp. 113-129. In: Využití kultur rostlinných explantátu ve šlechténí (Use of Tissue Cultures in Plant Breeding) Sborník z medzinárodního symposia, Olomouc.

OPATRNY Z., 1983. Hormonal regulation of morphogenesis in cell cultures (in Czech), pp. 16-26. In: Dny rostlinné fyziologie III., Sborník referátu, Praha.

OSTROLUCKÁ M.G., 1993. Possibilities of in vitro methods in propagation of Actinidia chinensis (in Slovak), pp. 85-91. In: 100 výročie šl'achtenia ovocia na Hornej Nitra, 1893-1993. Medzinárodné sympózium VÚ OOD Bojnice.
OSTROLUCKÁ M.G., KRAJMEROVÁ D., 1996. Manifestation of embryogenic potential in culture of zygotic embryos of Quercus robur L. Acta Soc. Bot. Pol. 65: 37-41.

STANDARDI A., 1983. La micropropagazione nella moltiplicazione dell actinidia. Frutticoltura 45: 17-22.

VIEITEZ A.M., GONZALES M.L., VIEITEZ E., 1978. In culture of cotyledon tissue of Castanea sativa Mill.. Scientia Horticulturae 8: 243-247.

VIEITEZ A.M., SAN-JOSÉ M.C., 1996. Adventitious shoot regeneration from Fagus sylvatica leaf explants in vitro. In vitro Cell. Dev. Biol. Plant 32: 140-147.

WANG J.X., LI S.Z., LI B.W., REN E.Y., 1982. Propagation of Actinidia chinensis by tissue culture. Ligoning Agric. Sci. 1: 32-34.

\title{
PROCESY MORFOGENETYCZNE W KULTURACH TKANKOWYCH KALUSA I REGENERACJA ROŚLIN U ACTINIDIA CHINENSIS PLANCH.
}

\begin{abstract}
STRESZCZENIE
Stwierdzono wysoką zdolność regeneracyjną Actinidia chinensis w warunkach in vitro. W niniejszych badaniach wykazano: dużą zdolność eksplantatów z liści Actinidia chinensis do indukcji, intensywne rozmnażanie się kultur kalusa oraz możliwość regulowania morfogenezy w warunkach in vitro. W określonych warunkach kultury potencjał morfogenetyczny kalusa. Actinidia chinensis przejawiał się zarówno w organogenezie, jak i somatycznej embriogenezie. Organogeneza polegała na indukcji pạków przybyszowych i regeneracji pędów na zmodyfikowanej pożywce MS (Murashige i Skoog 1962) z dodatkiem BAP w kombinacji z GA3 (po $1,0 \mathrm{mg}^{-1} \mathrm{1}^{-1}$ ). Ukorzenianie się pędów było pomyślne na zmodyfikowanej pożywce MS zawierającej IBA $\left(0,5-1,0 \mathrm{mg} \cdot \mathrm{1}^{-1}\right)$. Badania histologiczne tkanek kalusa wykazały ich strukturalną niejednorodność. Procesy morfogenetyczne charakteryzowały się pojawianiem się stref merystematycznych i elementów naczyniowych. Tworzenie się merystemu wierzchołkowego, zawiązków liści oraz rozwój pędów potwierdziło zachodzenie regeneracji w kulturze kalusa. Uzyskane rezultaty prezentują wydajny system regeneracji roślin poprzez pośrednią organogenezę, który wykorzystać można do rozmnażania Actinidia chinensis.
\end{abstract}

SŁOWA KLUCZOWE: Actinidia chinensis, eksplantat z liści, kultura kalusowa, reakcje morfogenetyczne. 